Jurnal Inkofar* Volume 1 No. 2, Desember 2017 * ISSN: 2615-3645 (Print) / 2581-2920 (Online)

Tersedia secara online di: http://www.politeknikmeta.ac.id/meta/ojs/

\title{
ANALISA EFEKTIFITAS DAN KEPUASAN PENGGUNA WEBSITE KECAMATAN JONGGOL
}

\author{
Andi Arfian \\ Program Studi Sistem Informasi STMIK Nusa Mandiri Jakarta \\ Email: andi.afn@bsi.ac.id
}

\begin{abstract}
In carrying out the Information Dissemination required good planning. Furthermore, to make good planning requires accurate and actual information and data, both for general and qualitative information. Village administrative apparatus required extensive information facilities. In this research the author tries to analyze the utilization of Web Based information that is website for village society in sub district of jonggol. In analyzing the author using Delone and McLean methods in analyzing the utilization rate and satisfaction by using the method of PLs sam. And from the results of the study are still many shortcomings and needs that must be fixed one of them still imagine the information from the population in the district of jonggol and expected future can be the basis of information in the development of information more interactive and beneficial for the villagers in the district Jonggol district Bogor.
\end{abstract}

Keywords: Sem, Delone and Mc lean, Pls

\begin{abstract}
ABSTRAK
Dalam melaksanakan sistem informasi diperlukan perencanaan yang baik. Selanjutnya, untuk membuat perencanaan yang baik membutuhkan informasi dan data yang akurat dan aktual, baik untuk informasi umum maupun kualitatif. Aparat administratif desa membutuhkan fasilitas informasi yang luas. Dalam penelitian ini penulis mencoba menganalisis pemanfaatan informasi Berbasis Web yaitu website untuk masyarakat desa di kecamatan jonggol. Dalam menganalisis penulis menggunakan metode Delone dan McLean dalam menganalisis tingkat pemanfaatan dan kepuasan dengan menggunakan metode PLs sam. Dan dari hasil penelitian masih banyak kekurangan dan kebutuhan yang harus diperbaiki salah satunya masih terbayang informasi dari penduduk di kabupaten jonggol dan diharapkan kedepannya dapat menjadi dasar informasi dalam pengembangan informasi yang lebih interaktif dan bermanfaat untuk warga desa di kecamatan Jonggol kabupaten Bogor.
\end{abstract}

Kata Kunci: Sem, Delone dan Mc lean, Pls

\section{PENDAHULUAN}

Kemajuan dan insfrastruktur internet di Indonesia sekarang ini khususnya kehadiran teknologi informasi yang berbasiskan internet sudah terbilang maju dan tidak ketingilan pula dengan di institusi pemerintah ditandai dengan munculnya berbagai website di tiap-tiap instansi pemerintah yang . Website Kecamatan Jonggol beralamatkan di www.Kecamatanjonggol.kabbogor.go.id berfungsi sebagai sarana informasi kegiatan serta program pemerintah daerah dalam memberi layanan informasi. Setelah layanan website tersebut diimplementasikan belum pernah dilakukan evaluasi pemanfaatan dan efektifitas informasi mengenai website Kecamatan Jonggol berdasarkan persepsi pengguna akhir atau pengunjung situs sebagai umpan balik ke pihak pengelola website (manajemen). Pada dasarnya untuk sekarang ini seseorang akan mencari informasi yang cepat dan mudah dengan menggunakan layanan web site ${ }^{[1]}$. Pengguna akan merasa terpuaskan jika layanan website yang dibuka tersebut sesuai dengan persepsi tentang mutu layanan informasi yang saat ini dirasakan dan tingkat harapan masa datang. Pemanfaatan dan kegunaan website dilihat dari seberapa baik fungsi dan seberapa efektif pengguna dapat bernavigasi merupakan salah satu faktor kunci kualitas layanan website $^{[2]}$. Berdasarkan evaluasi diatas maka penulis melakukan Penelitian ini mencoba melakukan evaluasi Pemanfaatan dan efektifitas layanan website Kecamatan Jonggol Kabupaten Bogor dari persepsi pengguna yang menitik beratkan sejauh mana persepsi tentang mutu layanan website yang dirasakan (aktual) dengan tingkat harapan (ideal) sehingga dapat diketahui atribut atau fitur website apa saja yang sudah baik atau yang masih memerlukan perbaikan. Hasil dari penelitian ini diharapkan dapat memberikan umpan balik bagi pihak manajemen (tim pengelola) layanan website Kecamatan 
Jonggol dalam perbaikan dan pengembangan website agar dapat meningkatkan kualitas layanan website sesuai harapan penggunanya. Berdasarkan latar belakang permasalahan tersebut, maka perumusan masalah yang akan diteliti sebagai berikut:

1. Mengeksplorasi hubungan antara kualitas layanan website, tingkat kepuasan pengguna dan intensitas penggunaan layanan website Kecamatan Jonggol dalam kerangka pemodelan persamaan struktural.

2. Sejauh mana hubungan tingkat harapan pengguna akan layanan website yang ideal dengan persepsi pengguna terhadap kualita s layanan website yang dirasakan saat ini;

3. Solusi dan implikasi manajerial yang dapat direncanakan untuk meningkatkan kualitas layanan website dalam memenuhi harapan penggunanya.

Kualitas bukan merupakan konsep yang baru dalam penelitan dan manajemen sistem informasi, khususnya sistem informasi berbasis web, yang diartikan sebagai kumpulan halaman yang menampilkan informasi teks,gambar diam atau gerak, animasi, suara, dan atau gabungan dari semuanya baik yang bersifat statis maupun dinamis yang membentuk suatu rangkaian bangunan yang saling terkait dan dihubungkan dengan jaringan-jaringan halaman (hyperlink). Kriteria sebuah situs web dengan kualitas yang baik adalah interaktif, representatif, ringkas dan sederhana, aman dan terjamin, dan desain yang menarik [3]. Para peneliti di bidang sistem informasi menyadari kebutuhan untuk meningkatkan fungsi dari layanan website agar dapat memberikan reaksi terhadap tekanan internal maupun eksternal serta tantangan dan kritik yang dihadapi agar kualitas layanan tersebut dapat semakin tumbuh dan bertahan. Arah perilaku pengguna dalam menerima sebuah teknologi ditentukan oleh persepsi kegunaan dan kemudahan penggunaan dari teknologi dan perilaku ini mempengaruhi intensitas pengguna untuk menggunakan teknologi tersebut [4]. Kualitas informasi (information quality) dan kualitas pelayanan (service quality) berpengaruh positif terhadap tingkat kepuasaan pengguna dan intensitas penggunaan layanan suatu sistem informasi. Semakin baik kualitas layanan suatu website yang diberikan, maka semakin besar tingkat kepuasan dan semakin sering seseorang menggunakan layanan tersebut. Semakin besar tingkat kepuasan seseorang akan suatu layanan website maka semakin tinggi intensitas seseorang menggunakan layanan tersebut [5]. Dalam penelitian ini adalah memfokuskan pada pengunaan tingkat kepuasan pengguna dalam mendapatkan informasi. Penelitian ini disusun berdasarkan teori-teori tentang kesuksesan dalam pengimplementasikan pemanfaatan pengunaan teknologi infomasi (Techologi acceptance model), Secara umum model penelitian ini mengacu pada model De lone \& Mclean yang telah diperbaharui (2003). Tujuan yang ingin dicapai dalam penelitian ini sebagai berikut:

1. Melakukan evaluasi kualitas website Kecamatan Jonggol kabupaten Bogor;

2. Mengetahui hubungan antara tingkat kepuasan dan intensitas pengguna website ;

3. Mengetahui hubungan tingkat harapan dan persepsi pengguna terhadap kualitas layanan yang diberikan website Kecamatan Jonggol;

4. Mengetahui keberhasilan implementasi layanan website Kecamatan Jonggol.

\section{BAHAN DAN METODE}

\subsection{Sistem Informasi}

Definisi menurut Tata Sutabri (2007, p.2) sistem adalah suatu kumpulan atau himpunan dari unsur - unsur, komponen atau variable yang terorganisir, saling berintegrasi, saling berinteraksi, saling tergantung satu sama lain dan terpadu. Sistem informasi adalah suatu sistem di dalam suatu organisasi yang mempertemukan kebutuhan pengolahan transaksi harian, mendukung operasi, bersifat manajerial dan kegiatan strategi dari suatu organisasi dan menyediakan pihak luar tertentu dengan laporan-laporan yang diperlukan Jogiyanto (2008, p.11). 


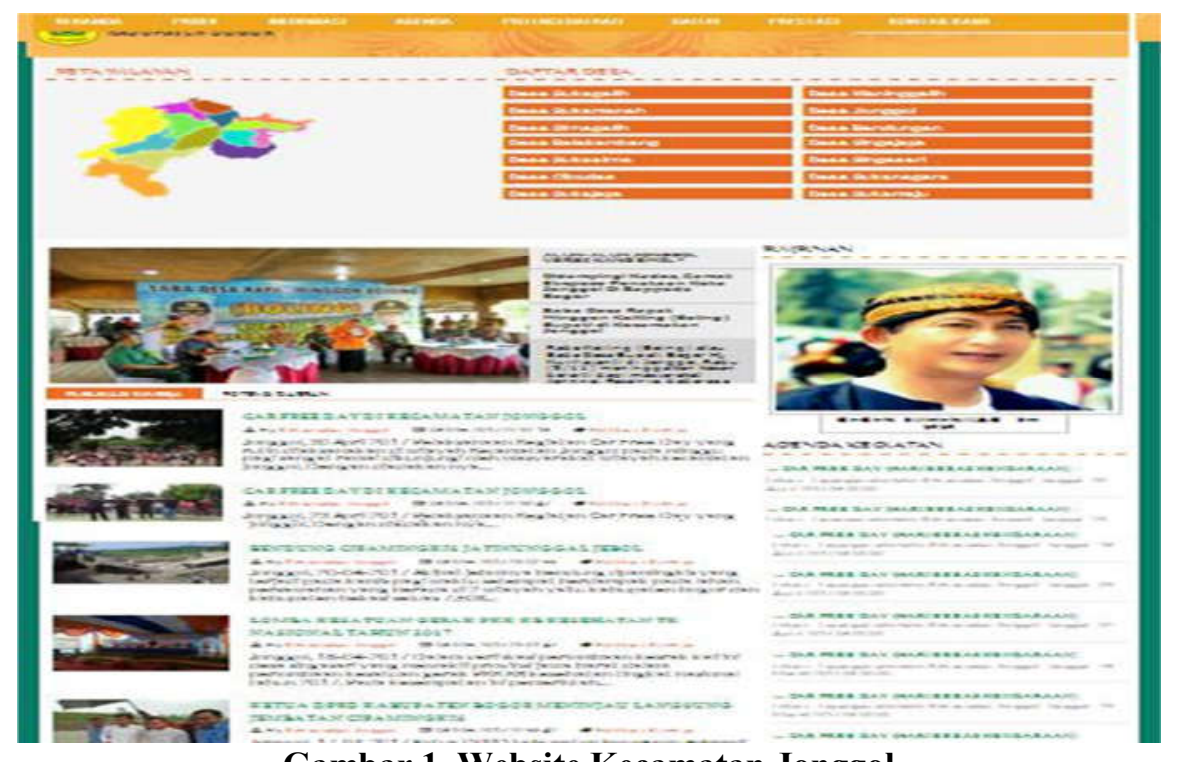

Gambar 1. Website Kecamatan Jonggol

\subsection{Website}

Website atau situs juga dapat diartikan sebagai kumpulan halaman yang menampilkan informasi data teks, data gambar diam atau gerak, data animasi, suara, video dan atau gabungan dari semuanya, baik yang bersifat statis maupun dinamis yang membentuk satu rangkaian bangunan yang saling terkait dimana masing-masing dihubungkan dengan jaringan-jaringan halaman (hyperlink). Bersifat statis apabila isi informasi website tetap, jarang berubah, dan isi informasinya searah hanya dari pemilik website. Bersifat dinamis apabila isi informasi website selalu berubah-ubah, dan isi informasinya interaktif dua arah berasal dari pemilik serta pengguna website.

\subsection{Model kepuasan}

Kehadiran sistem teknologi informasi telah memberikan begitu banyak pengaruh terhadap sebuah organisasi, bukan hanya organisasi namun pengaruh tersebut meluas hingga proses bisnis dan transaksi organisasi. Namun apakah semua sistem teknologi informasi yang diterapkan pada organisasi dapat dikategorikan sukses? Lalu bagaimana organisasi dapat mengetahui kesuksesan sistem teknologi informasi yang diterapkan dan bagaimana membuat sistem teknologi informasi menjadi sukses. Banyak penelitian telah dilakukan untuk mengidentifikasikan faktor-faktor yang menyebabkan kesuksesan sistem teknologi informasi. Salah satu penelitian yang terkenal di area ini adalah penelitian yang dilakukan oleh DeLone \& McLean (1992). Model kesuksesan sistem teknologi informasi yang dikembangkan oleh DeLone \& McLean (1992) ini cepat mendapat tanggapan. Salah satu sebabnya adalah model mereka merupakan model yang sederhana tetapi dianggap cukup valid. Model yang baik adalah model yang lengkap tetapi sederhana. Model semacam ini disebut dengan model yang parsimoni. Berdasarkan teori-teori dan hasil penelitian sebelumnya yang telah dikaji, DeLone \& McLean (1992) kemudian mengembangkan suatu model parsimoni yang mereka sebut dengan nama model kesuksesan sistem informasi DeLone \& McLean (D\&M Information System Success Model) sebagai berikut ini: 


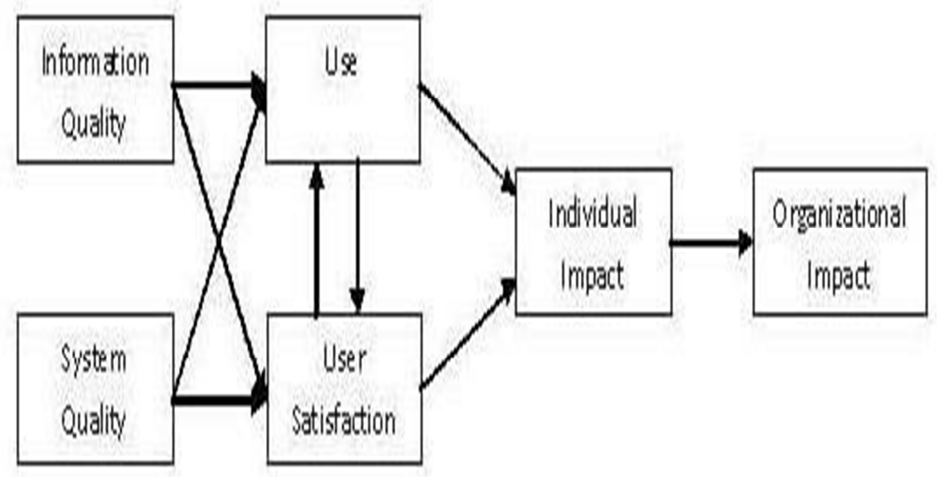

Gambar 2. Model DeLone \& McLean (1992)

Model yang diusulkan ini merefleksi ketergantungan dari enam pengukuran kesuksesan sistem informasi. Keenam elemen atau faktor atau komponen atau pengukuran dari model ini adalah:

a) Kualitas system (system quality)

b) Kualitas informasi (information quality)

c) Penggunaan (use)

d) Kepuasan pemakai (user satisfaction)

e) Dampak individual (individual impact)

f) Dampak organisasional (organizational impact)

Model kesuksesan ini didasarkan pada proses dan hubungan kausal dari dimensi-dimensi di model. Model ini tidak mengukur ke enam dimensi pengukuran kesuksesan sistem informasi secara independen tetapi mengukurnya secara keseluruhan satu mempengaruhi yang lainnya. Pertimbangan proses berargumentasi bahwa suatu sistem terdiri dari beberapa proses, yaitu satu proses mengikuti proses yang lainnya. Berbeda dengan model proses, model kausal (model causal) atau disebut juga dengan model varian (variance model) berusaha untuk menjelaskan kovarian (covariance) dari elemen-elemen model untuk menentukan apakah variansi dari satu elemen dapat dijelaskan oleh variansi dari elemen-elemen lainnya atau dengan kata lain untuk menentukan apakah terjadi hubungan kausal diantara mereka. Model kausal ini menunjukkan bagaimana arah hubungan satu elemen dengan elemen lain apakah menyebabkan lebih besar (mempunyai pengaruh positif) atau lebih kecil (mempunyai pengaruh negatif). Dari model proses dan kausal ini, maka dapat dijelaskan bahwa kualitas sistem (system quality) dan kualitas informasi (information quality) secara mandiri dan bersama-sama mempengaruhi baik penggunaan (use) dan kepuasan pemakai (user satisfaction). Besarnya penggunaan (use) dapat mempengaruhi kepuasan pemakai (user satisfaction) secara positif atau negatif. Penggunaan (use) dan kepuasan pemakai (user satisfaction) mempengaruhi dampak individual (individual impact) dan selanjutnya mempengaruhi dampak organisasional (organizational impact).

\subsection{Kritik Seddon (1997)}

Model DeLone \& Mclean (1992) banyak mengundang perhatian dari para peneliti, salah satunya adalah Peter B. Seddon yang melontarkan kritik terhadap model yang diajukan oleh DeLone \& Mclean. Menurut Seddon (1997) masalah utama dari model D\&M (DeLone \& McLean) adalah mencoba mengkombinasikan proses dan penjelasan kausal dari kesuksesan sistem informasi di model mereka. Dengan demikian model mereka tercampur antara model proses (process model) dan model varian (variance model). Model varian (variance model) dapat diuji secara empiris dengan mengumpulkan data dalam bentuk sampel, mengukur variabel-variabelnya dan menggunakan teknik statistik seperti regresi, SEM dan lain sebagainya, untuk menginferensi populasinya. Secara kontras, model proses (process model) menunjukkan kombinasi tertentu dari kejadian-kejadian (events) dalam urutan-urutan tertentu yang mengakibatkan suatu hasil (outcomes). Model proses dan model varian mengandung konsep yang berbeda dan tidak dapat digabungkan dengan arti yang sama begitu saja. Lebih lanjut, Seddon (1997) mengatakan bahwa kotak-kotak dan arah panah di model D\&M dapat diintepretasikan keduanya yaitu suatu varian dan suatu kejadian di dalam proses. Dalam usaha 
mengatasi kesulitan-kesulitan di model D\&M ini, Seddon (1997) mencoba melakukan spesifikasi ulang dan mengembangkan sedikit versi dari model D\&M. Model yang dispesifikasi ulang ini tetap mempertahankan fitur-fitur di model D\&M tetapi menghilangkan kebingungan yang disebabkan oleh arti ganda dari kotak-kotak dan arah-arah panahnya. Spesifikasi ulang ini dilakukan dengan memecah model D\&M menjadi dua submodel-submodel varian (yaitu Use dan Success) .

2.5 Structural Equation Modeling (SEM)

SEM, adalah suatu teknik modeling statistik yang bersifat sangat cross-sectional, linear dan umum. Termasuk dalam SEM ini ialah analisis faktor (factor analysis), analisis jalur (path analysis) dan regresi (regression). Definisi lain menyebutkan structural equation modeling (SEM) adalah teknik analisis multivariat yang umum dan sangat bermanfaat yang meliputi versi-versi khusus dalam jumlah metode analisis lainnya sebagai kasus-kasus khusus. Definisi berikutnya mengatakan bahwa Structural equation modeling (SEM) merupakan teknik statistik yang digunakan untuk membangun dan menguji model statistik yang biasanya dalam bentuk model-model sebab akibat. Structural Equation Modelling (SEM) merupakan teknik analisis multivariat yang dikembangkan guna menutupi keterbatasan yang dimiliki oleh model-model analisis sebelumnya yang telah digunakan secara luas dalam penelitian statistik. Analisis SEM yang digunakan dalam penelitian ini, merupakan SEM berbasis kovarians (CB-SEM atau Covarians Based-Structural Equation Modelling) yang melakukan interkolasi atau membebaskan indikator-indikatornya untuk saling berkorelasi dengan indikator dan variabel laten lainnya dengan pengolahan datanya menggunakan software SmartPls. Tahapan analisis SEM pada penelitian ini dimulai dengan membuat sebuah model SEM. Kemudian dilakukan pengujian model dengan asumsi-asumsi yang seharusnya dipenuhi dalam SEM. Setelah itu dilakukan uji identifikasi model, yaitu apakah model dapat di analisis lebih lanjut. Menguji model (model testing dan model estimasi) dilakukan dengan cara uji measurement model dan uji structural model. Dari uji measurement model akan didapat keeratan hubungan antar indikator dengan konstruknya. Jika measurement model dianggap valid, pengujian dilanjutkan pada structural model untuk memperoleh sejumlah korelasi yang menunjukkan hubungan antar kostruk

\section{KERANGKA BERFIKIR}

Dalam Penelitian ini penulis mengunakan variable dari Model DeLone dan McLean (2003) yaitu kualitas sistem (system quality), kualitas informasi (information quality), kualitas layanan (service quality), penggunaan (use), kepuasan pemakai (user satisfaction) dan manfaat-manfaat bersih (net benefit). Model kerangka teori dibuat berdasarkan teori dari model kesuksesan sistem informasi DeLone dan McLean yang dimodifikasi Mc Gill, et al. (2003). Hubungan antar variabel ini dapat dilihat dari gambar berikut

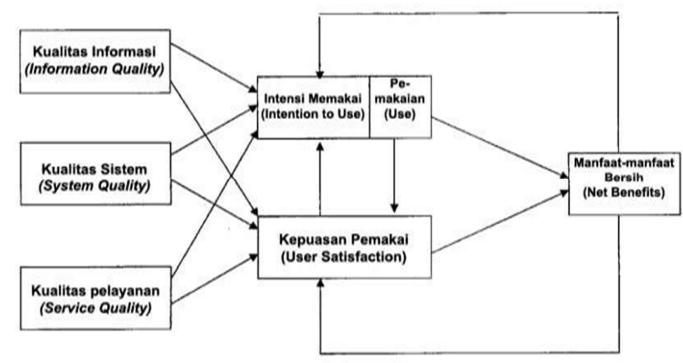

Gambar 3. Model DeLone \& McLean (2003)

\subsection{Hipotesis}

Hipotesis berasal dari bahasa Yunani hypo yang berarti di bawah dan thesis yang berarti pendirian, pendapat yang ditegakkan, kepastian. Jika dimaknai secara bebas, maka hipotesis berarti pendapat yang kebenarannya masih diragukan. Untuk bisa memastikan kebenaran dari pendapat tersebut, maka suatu hipotesis harus diuji atau dibuktikan kebenarannya. Untuk membuktikan kebenaran suatu hipotesis, seorang peneliti dapat dengan sengaja menciptakan suatu gejala, yakni melalui percobaan 
atau penelitian. Jika sebuah hipotesis telah teruji kebenarannya, maka hipotesis akan disebut teori. Dalam penelitian ada dua jenis hipotesis yang seringkali harus dibuat oleh peneliti, yakni hipotesis penelitian dan hipotesis statistik. Berdasarkan landasan teori dan kerangka berfikir maka disusun hipotesis sebagai berikut:

1. Kualitas sistem terhadap penggunaan system

a) $\operatorname{Ho}(1)$ : Tidak terdapat hubungan positif dan siginifikan antara variable Kualitas sistem (system quality) dengan penggunaan (use).

b) $\mathrm{Ha}(1)$ : Terdapat hubungan positif dan siginifikan antara variable Kualitas sistem (system quality) dengan penggunaan (use)

2. Kualitas sistem terhadap kepuasan pengguna

a) $\operatorname{Ho}(2)$ : Tidak terdapat hubungan positif dan siginifikan antara variable kualitas sistem (sistem quality) dengan kepuasan pengguna (user satisfaction).

b) $\mathrm{Ha}(2)$ : Terdapat hubungan positif dan siginifikan antara variable Kualitas sistem (sistem quality) dengan kepuasan pengguna(user satisfaction).

3. Kualitas informasi terhadap penggunaan system

a) $\operatorname{Ho}(3)$ : Tidak terdapat hubungan positif dan siginifikan antara variable kualitas informasi (information quality) dengan penggunaan (use).

b) $\mathrm{Ha}(3)$ : Terdapat hubungan positif siginifikan antara variable kualitas informasi (information quality) dengan penggunaan (use).

4. Kualitas informasi terhadap kepuasan pengguna :

a) $\mathrm{Ho}(4)$ : Tidak terdapat hubungan positif dan siginifikan antara variable kualitas informasi (information quality) dengan kepuasan pengguna (user satisfaction).

b) $\mathrm{Ha}(4)$ : Terdapat hubungan positif dan siginifikan antara variable kualitas informasi (information quality) dengan kepuasan pengguna (user satisfaction).

5. Kualitas layanan terhadap penggunaan.

a) $\operatorname{Ho}(5)$ : Tidak terdapat hubungan positif dan siginifikan antara variable kualitas layanan (service quality) dengan penggunaan (use).

b) Terdapat hubungan positif dan siginifikan antara variable kualitas layanan (service quality) dengan penggunaan (use).

6. Kualitas layanan terhadap kepuasan pengguna

a) $\mathrm{Ho}(6)$ : Tidak terdapat hubungan positif dan siginifikan antara variable kualitas layanan (service quality) dengan kepuasan pengguna (user satisfaction).

b) $\mathrm{Ha}(6)$ : Terdapat hubungan positif dan siginifikan antara variable kualitas layanan (service quality) dengan kepuasan pengguna (user satisfaction).

7. Penggunaan sistem terhadap kepuasan pengguna.

a) $\operatorname{Ho}(7)$ : Tidak terdapat hubungan positif dan siginifikan antara variable penggunaan (use) dengan kepuasan pengguna (user satisfaction).

b) $\mathrm{Ha}(7)$ : Terdapat hubungan positif dan siginifikan antara variable penggunaan (use) dengan kepuasan pengguna (user satisfaction).

8. Penggunaan terhadap manfaat-manfaat bersih.

a) $\operatorname{Ho}(8)$ : Tidak terdapat hubungan positif dan siginifikan antara variable penggunaan (use) dengan manfaat-manfaat bersih (net benefit).

b) $\mathrm{Ha}(8)$ : Terdapat hubungan positif dan siginifikan antara variable penggunaan (use) dengan manfaat-manfaat bersih (net benefit).

9. Kepuasan pengguna terhadap manfaat-manfaat bersih.

a) $\operatorname{Ho}(9)$ : Tidak terdapat hubungan positif dan siginifikan antara variable kepuasan pengguna (user satisfaction) dengan manfaat-manfaat bersih (net benefit).

b) $\mathrm{Ha}(9)$ : Terdapat hubungan positif dan siginifikan antara variable kepuasan pengguna (user satisfaction) dengan manfaat-manfaat bersih (net benefit).

Pengujian hipotesis penelitian merujuk pada menguji apakah hipotesis tersebut betul-betul terjadi pada sampel yang diteliti atau tidak. Jika apa yang ada dalam hipotesis benar-benar terjadi, maka hipotesis penelitian terbukti, begitu pun sebaliknya. Sementara itu, pengujian hipotesis statistik berarti menguji apakah hipotesis penelitian yang telah terbukti atau tidak terbukti berdasarkan data sampel tersebut dapat diberlakukan pada populasi atau tidak. Berdasarkan pemaparan mengenai model 
kesuksesan sistem informasi menurut De lone dan Mc Lean, maka disusun beberapa hipotesis sebagai berikut:

1. Apakah kualitas informasi berpengaruh positif terhadap kepuasan pengguna Website Kecamatan Jonggol ?

2. Apakah kualitas sistem berpengaruh positif terhadap kepuasan pengguna Website?

3. Apakah kualitas layanan berpengaruh positif terhadap kepuasan pengguna Website ?

4. Apakah kualitas informasi berpengaruh positif terhadap intensitas penggunaan Website ?

5. Apakah kualitas sistem berpengaruh positif terhadap intensitas penggunaan Website ?

6. Apakah kualitas layanan berpengaruh positif terhadap intensitas penggunaan Website ?

7. Apakah intensitas penggunaan sistem dan kepuasan pengguna sistem berpengaruh positif terhadap net benefit ?

\subsection{Metode Penelitian}

Jenis atau metode yang digunakan dalam penelitian ini adalah uji hipotesis, yang bertujuan untuk menguji dan menjelaskan kareteristik hubungan-hubungan tertentu, pengaruh atau perbedaan antar kelompok atau independen daru dua faktor atau lebih dalam satu situasi. Pengujian hipotesis ini dilakukan untuk menguji struktur hubungan kausal antara faktor faktor yang mempengaruhi penerimaan teknologi khususnya pemanfaatan web Kecamatan jonggol di kabupaten Bogor bagi masyarakat. Variabel yang digunakan pada penelitiaan ini adalah variable yang dapat diukur dengan secara langsung (Laten Variabel) yaitu :

1. Variabel Eksogen(contruc Exogen)Sebagai variabel indepeden $\mathrm{x}$ yang terdiri dari

a) Kualitas Informasi (KI)

b) Kualitas Sistem (KS)

c) Kualitas Layanan (KL)

2. Variabel Endogen (Construk Endogen) sebagai Variabel dependent (Y) Yaitu :

a) Intensistas Pemakai (IP)

b) Tingkat Kepuasan (KP)

c) Manfaat (M)

Metode pengumpulan data yang digunakan yaitu metode study pustaka dengan mengumpulkan data dan informasi yang bersifat sekunder yaitu data data diperoleh memlalaui buku buku referensi tentang penelitian mengunakan metode model De lone dan Mc Lean, dan tulisan ilmiah tentang analisa pemanfaatan dan kepuasan web. Penelitiaan ini mengunakan instrumen kuesioner yang bersifat closed, metode ini dapat mempermudah responden dapat dengan mudah menjawab kuesioner dan mengolah data lebih cepat dianalisa secara statistik .

\subsection{Analisa Data}

Analisa data yang dilakukan pada penelitiaan ini adalah analisa statistik deskriptip dan analisa statistik Inferensial. Ukuran pemusatan ditelaah meliputi enam Mean, Median dan Modus deviasi dan varian. Struktur Equation Model (SEM) dengan tujuan memperoleh model yang sesuai bagi permasalahan yang akan diteliti. Selain itu dapat pula mengetahui hubungan kausal antara variabel dependen dan independen dalam penelitian ini. Pengembangan sebuah model dari SEM berdasarkan hubungan kualitas antara variabel yang diajukan terletak apada pembenaran secara teoritis untuk mendukung analisis, dikembangkan konstruk (faktor yang diteliti) dengan indikator-indikator sebagai berikut :

1. Kontruk Eksogen (X) sebagai source variable atau independen variable yang diprediksi oleh variable lain. Dalam penelitiann ini meliputi : Kualitas Informasi, Kualitas Sistem, Kualitas Layanan.

2. Kontruk Endogen (Y) yaitu yang hanya berhubungan kausal (sebab akibat) dengan kontruk endogen yaitu: Intesitas Pemakai, Tingkat Kepuasaan dan Manfaat.

Dalam Penelitian ini mengunakan perangkat lunak SmartPLS untuk melakukan estimasi dari model yang dikembangkan sereta matrix input yang dipilih debgan teknik estimasi Maximum Likelihood (ML).Penelitian ini dilakukan untuk mengetahui seberapa jauh model persamaan struktural yang dihipotesiskan sesuai dengan sample data. Penilaian ini dilakukan dengan uji asumsi SEM, Uji kesesuaian model (Overall model Fit), Uji Parameter Model. Dan uji Realibilitas. 


\section{HASIL DAN PEMBAHASAN}

Berdasarkan hasil penelitian faktor- faktor yang mempengaruhi efektifitas teknologi pemanfaatan web informasi pemerintah di wilayah jonggol dengan beragam penguna dan variabel indepeden atau konstruk eksogen yang terdiri dari dua variabel yang tidak bisa diukur secara langsung (variabel laten) yaitu laten laten variabel eksogen sebagai variabel indepeden $(\mathrm{X})$ dan laten variabel endogen sebagai variabel dependen (Y). Uji validitas dan Realibilias Pengujian Model pertama dengan mengunakan software Smart PIS dengan pengujian Outer Model pertama didapat hasil yaitu

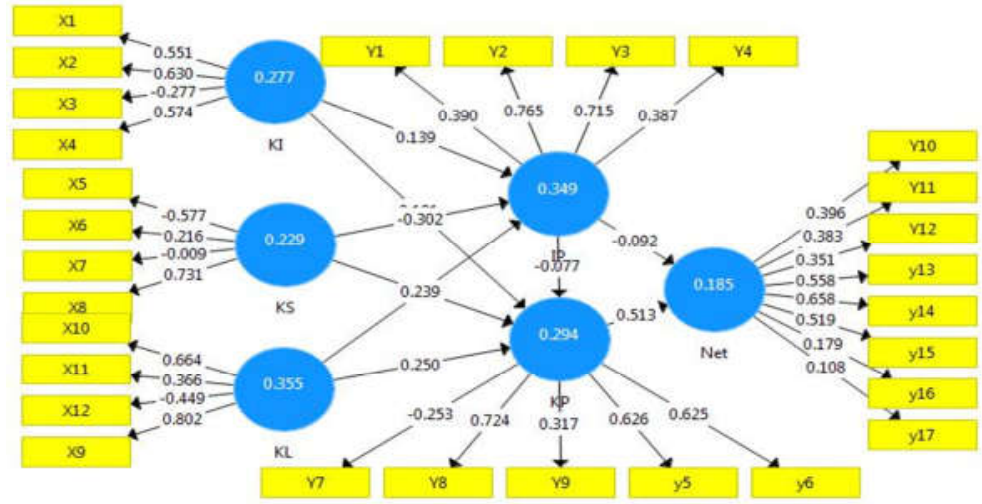

Gambar 3. Hasil Uji Model Awal

Gambar 3 adalah output program Smart Pls yang digunakan sebagai acuan sebagai uji validitas dan reliabilitas karena terlihat loading factornya. Selain menggunakan loading factor pada uji validitas dan reliabilitas, cross loading juga diperlukan dalam mengetahui kekonvergenan data. Adapun uji validitas dan reabilitas dapat dilihat secara rinci pada tabel dibawah ini :

\begin{tabular}{|c|c|c|c|c|c|}
\hline Indlcator & variabel & Nilal & Indicator & Variabel & Nillal \\
\hline $\mathbf{0}$ & 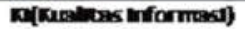 & D.6 & $\mathbf{n}$ & - (WTEMAS VENGLWA) & 0.4 \\
\hline$x \mathbf{x}$ & 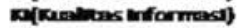 & 26 & $\boldsymbol{z}$ & W (WTESTAS FENGLNA) & a.8 \\
\hline $\mathbf{x}$ & 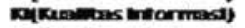 & 0 & $\mathbf{r}$ & - IETESTAS PENGLNA) & $=3$ \\
\hline$\infty$ & 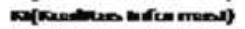 & a a & $m$ & 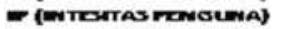 & 0,4 \\
\hline so & 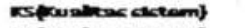 & 26 & vo & 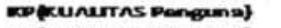 & 0.6 \\
\hline$\times 6$ & Estounations ststem] & 0.2 & ro & copixuaurtas Penquma\} & 0.6 \\
\hline $\boldsymbol{x} \boldsymbol{\sigma}$ & ISpouabcas ststem\} & - & $\mathbf{r}$ & wopuaurras Pengunal & $-0,3$ \\
\hline$\times$ & Esfouabcas sestemy & a.7 & ro & Dop (kuaurtas pengumaj & 0,7 \\
\hline$x$ & Mcas Lapanany & ux & $\boldsymbol{x}$ & 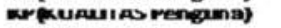 & 0,3 \\
\hline san & 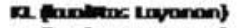 & a) & no & WET (Whonfinat) & 0.4 \\
\hline $\mathbf{x a}$ & 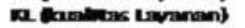 & $=4$ & max & 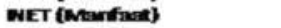 & 0.4 \\
\hline \multirow[t]{4}{*}{$x$} & 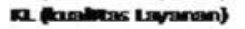 & $\rightarrow a$ & nz & WET (Wtomfand) & 0.4 \\
\hline & & & $\mathbf{n z}$ & WET (Mtanfiane) & 0.6 \\
\hline & & & $\mathrm{req}$ & me I (wranfase) & גנ \\
\hline & & & $m$ & WET (Monomfine) & $a=$ \\
\hline
\end{tabular}

Tabel 1.

Tabel 1 merupakan nilai dari cross loading dan loading factor ditunjukkan oleh nilai dari cell cross loading yang bercetak tebal dan bergaris bawah. Pada cell yang angkanya bercetak tebal menunjukkan data tidak valid, sedangkan pada cell yang angkanya bergaris bawah menunjukkan data valid. Selanjutnya nilai yang tidak valid akan dihapus dari model awal . kemudian akan diuji kembali agar menghasilkan nilai yang diinginkan. Dapat dilihat pada Tabel 3 bahwa terdapat 10 indikator yang tidak valid yaitu, indikator X3, X6, X7, X11,X12, Y1, Y3, Y7, Y9,Y10,Y11 dan Y12, sehingga indikator-indikator tersebut harus dihilangkan dan dilakukan pengujian ulang. Setelah indikatorindikator yang tidak valid dihilangkan kemudian dilakukan pengujian ulang, maka didapatkan output program sebagaimana Gambar 4. Dari hasil outer Model awal dapat kita simpulkan bahwa hasil dari uji model pertama (Gambar 3) masih terdapat path yang belum valid oleh karena itu maka akan di uji lagi dengan menghilangkan path yang tidak valid ( gambar-3) yang tidak memenuhi persyaratan karena hasilnya dibawah nilai yang direkomendasikan yaitu $>0.05$ (Ghozali:2008) . Dari hasil path yang diatas peneliti akan menguji kembali dengan outer model 2 . 


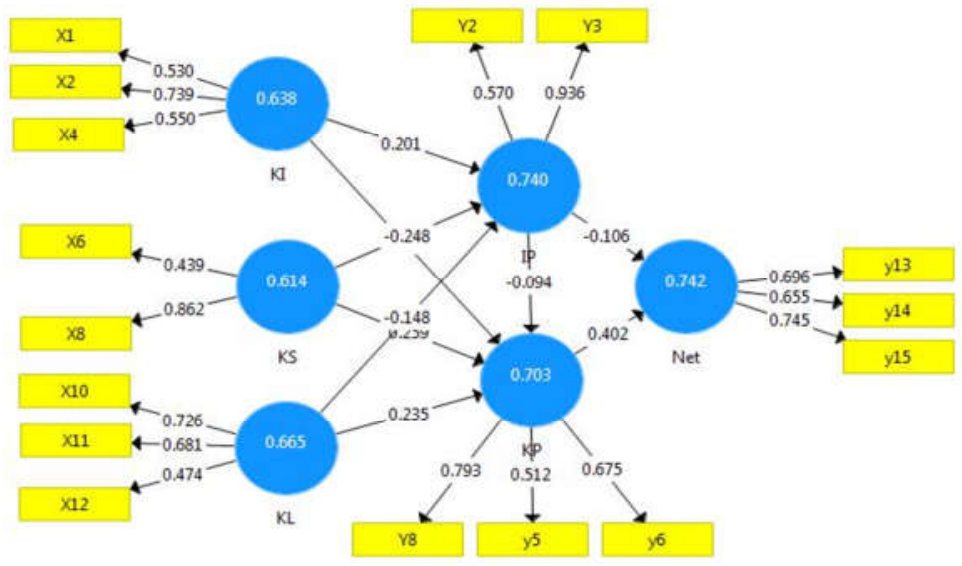

Gambar 4 .Uji Model 2 Hasil Modifikasi

\begin{tabular}{|c|c|c|c|c|c|}
\hline Indicator & varlabel & Nilal & Indkator & Varlabel & Nilal \\
\hline$\overline{x ב}$ & N(Kialens infirmad) & D.5 & $\mathbf{n}$ & IP (INIEBIAS PENGUNA) & R.9 \\
\hline$x z$ & N(Karites infomad) & D., & $n$ & IP (INIESIAS PENQUNA) & Q.5 \\
\hline $\mathbf{x a}$ & N(Kıalens infurmad) & Q.5 & $\mathbf{B}$ & IP (INIECIAS PENGUNA) & a.9 \\
\hline 256 & KS(Kunlths ststem) & aA & $\mathbf{5}$ & KP(RUNUIAS PEngum) & a.7 \\
\hline $\mathbf{x}$ & KS(Kuriles stiem) & D.9 & $\mathbf{6}$ & KP(La) & a.B \\
\hline $\mathbf{g}$ & R. (halles Lapan) & a.8 & $\mathbf{m g}$ & NET (Nantor) & a., \\
\hline nn & R. (halles lapma) & a. & n3 & NET (Nambit) & a. \\
\hline m & 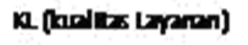 & a.j & na & NET (Wanforl) & a. \\
\hline $\mathbf{m z}$ & 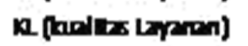 & a.5.5 & ns & NET (Nanteri) & a) \\
\hline
\end{tabular}

Tabel 2 . Hasil Modifikasi 3

Pengujian validitas tahap ketiga yaitu pengujian discriminant validity. Pengujian ini didasarkan dari nilai cross loading pengukuran dengan konstruk dan nilai Average Variance Extracted (AVE). AVE yang baik, disyaratkan oleh Ghozali memiliki nilai lebih besar dari 0,50[10]. Berikut ini merupakan nilai dari tabel AVE

\begin{tabular}{|l|r|}
\hline \multicolumn{1}{|c|}{ VARIABEL } & \multicolumn{1}{c|}{ AVE } \\
\hline INTENSISTAS PENGUNA & 0,7 \\
\hline KUALITAS INFORMASI & 0,5 \\
\hline KUALITAS LAYANAN & 0,5 \\
\hline KUALITAS PEMANFAATAN & 0,5 \\
\hline KUALITAS SISTEM & 0,6 \\
\hline MANFAAT & 0,6 \\
\hline
\end{tabular}

Tabel 3. Hasil Average

Tabel di atas menunjukkan nilai AVE dari model penelitian. Dapat dilihat tabel AVE Value untuk semua variabel penelitian telah bernilai di atas 0.5, sehingga nilai AVE untuk pengujian discriminant validity sudah memenuhi untuk pengujian selanjutnya.

\subsection{Pengujian Realibilitas}

Berdasarkan metode PLS, reliabilitas indikator refleksif pada penelitian ini ditentukan dari nilai composite reliability dan cronbach's alpha untuk setiap blok indikator first order pada konstruk reflektif. Rule of thumb nilai alpha atau composite reliability harus lebih besar dari 0,7 meskipun nilai 0,6 masih dapat diterima .Pengujian reliabilitas tahap selanjutnya adalah pengujian nilai croanbach's 
Jurnal Inkofar * Volume 1 No. 2, Desember 2017 * ISSN: 2615-3645 (Print) / 2581-2920 (Online)

Tersedia secara online di: http://www.politeknikmeta.ac.id/meta/ojs/

alpha. Konstruk dinyatakan reliabel jika memiliki nilai croanbach's alpha diatas 0,60 . Berikut hasil output dari outer model dari croanbach's alpha.

\begin{tabular}{|l|l|}
\hline Variabel & Cronbachs 'Alpha \\
\hline Kualitas Informasi & 0.61 \\
\hline Kualitas Sistem & 0.54 \\
\hline Kualitas Layanan & 0.56 \\
\hline Intesitas Penguna & 0.67 \\
\hline Kepuasan Penguna & 0.63 \\
\hline Manfaat Bersih (NET) & 0.56 \\
\hline
\end{tabular}

Tabel 4. Cronbach Alpha

croanbach's alpha dari model penelitian. Tabel tersebut menunjukkan bahwa setiap variabel telah memiliki nilai Cronbachs alpha di atas 0.5 dengan nilai terendah sebesar 0.54 dari variabel Kualitas Sistem (KS) dan nilai tertinggi sebesar 0.67 dari variabel Intensitas Penguna (IP). Dari hasil tersebut dapat disimpulkan bahwa model penelitian telah memenuhi nilai dari croanbach's alpha dengan Nilai Cukup Dari kedua model di atas, dapat disimpulkan bahwa model telah memenuhi kriteria Composite Reliability dan Croanbach's Alpha walaupun dengan nilai yang Cukup sehingga model penelitian tersebut telah memenuhi kriteria Reliabilitas dan merupakan alat ukur yang dapat dipercaya dan handal.

\subsection{Uji Koefisien Determinasi / $\mathbf{R}$ Square $\left(\mathbf{R}^{2}\right)$}

Evaluasi inner model dilakukan dengan melihat Koefisien Determinasi. Koefisien Determinasi bertujuan untuk mengukur seberapa jauh kemampuan model dalam menerangkan variansi variabel dependen. Nilai koefisien determinasi adalah antara 0 dan 1 . Jika nilai koefisien determinasi kecil atau bernilai dibawah atau sama dengan $0.500\left(\mathrm{R}^{2} \leq 0.500\right)$, berarti kemampuan variabel - variabel independen dalam menjelaskan variasi variabel dependen sangat terbatas. Sedangkan jika nilai koefisien determinasi besar dari $0.500\left(\mathrm{R}^{2}>0.500\right)$ berarti kemampuan variabel - variabel independen memberikan hampir seluruh informasi yang dibutuhkan untuk memprediksi variasi variabel dependen. Berikut adalah R-square pada konstruk berdasarkan output dari smartPLS 3.0

\begin{tabular}{|l|r|}
\hline \multicolumn{1}{|c|}{ VARIABEL } & Rsquare \\
\hline $\begin{array}{l}\text { INTENSISTAS } \\
\text { PENGUNA }\end{array}$ & 4,141 \\
\hline $\begin{array}{l}\text { KUALITAS } \\
\text { PENGUNA }\end{array}$ & 5,208 \\
\hline MANFAAT & 4,181 \\
\hline
\end{tabular}

Tabel 5. Hasil R-square

Berdasarkan Tabel $R$ Square $\left(\mathrm{R}^{2}\right)$ dapat disimpulkan bahwa kepuasan Pemakai dan Intensitas Pemakai mampu menjelaskan varians Manfaat Bersih sebesar 0.4181 atau $41 \%$ melalui hubungan linier. Sedangkan 0.60 atau $60.2 \%$ sisanya, dipengaruhi oleh variabel lain diluar penelitian ini.

\subsection{Uji Hipotesis}

SmartPLS 3.0 menggunakan nonparametric test untuk menentukan tingkat signifikan dari path coefficient, dimana nilai $\mathrm{t}$ (t-statistik) yang dihasilkan dengan menjalankan algoritma bootsraping pada smartPLS 3.0 digunakan untuk menentukan diterima atau tidaknya hipotesis yang diajukan. Cara pengujian hipotesis menggunakan smartPLS 2.0 adalah dengan melihat nilai Original Sample Estimate, Standard Error, dan i. Nilai pada Original Sample Estimate menunjukkan jenis hubungan antara variabel independen dan variabel dependen. Jika nilai Original Sample Estimate bernilai positif, maka hubungan antara kedua variabel adalah positif yang berarti jika terjadi kenaikan nilai pada variabel independen, maka akan diikuti dengan kenaikan nilai pada variabel dependen. Begitupun sebaliknya[10]. Selanjutnya dengan melihat nilai T-Statistic. Menurut Ghozali, nilai $T$ Statistic adalah nilai pengaruh masing-masing variabel bebasnya secara parsial (terpisah) terhadap variabel terikatnya. Uji ini dapat dilakukan dengan membandingkan T-Statistic smartPLS dengan t- 
tabel. Tingkat signifikansi $(\alpha)$ menunjukkan probabilitas atau peluang kesalahan yang ditetapkan peneliti dalam mengambil keputusan untuk menolak atau mendukung hipotesis nol. Pada penelitian kali ini, peneliti mengambil tingkat signifikansi sebesar 0.05 atau 5\%. Dengan derajat kebebasan (df) sebesar $95(\mathrm{n}-\mathrm{k}=95, \mathrm{n}=100, \mathrm{k}=5)$ dan tingkat signifikansi 0.05 , maka di dapat nilai $\mathrm{t}$ tabel sebesar 1,9852. Oleh karena itu, jika T-Statistik bernilai di atas atau sama dengan 1.985 ( T-Statistik $\geq$ 1.985 ), maka pengaruh yang diberikan oleh variabel independen terhadap variabel dependen adalah signifikan. Sedangkan jika T-Statistik bernilai di bawah 1.985 (T-Statistik $<1.985)$ maka pengaruh yang diberikan tidak signifikan.

\begin{tabular}{|l|c|c|c|c|c|}
\hline Path Variabel & ORGINAL_SA & MEAN & STDEV & T.Statistik & P value \\
\hline Intensitas Pemakai ->Kepuasan Pemakai & 0,7 & 0,6 & 0,2 & 4,2 & 0 \\
\hline Intensitas Pemakai ->Manfaat & $-0,4$ & 0,4 & 0,1 & 3,3 & 0 \\
\hline Kualitas Informasii->Intensitas Pemakai & 0,2 & 0,2 & 1 & 0,3 & 0 \\
\hline Kualitas Informasi->Kepuasan Pemakai & $-0,2$ & 0,2 & 0,2 & 2,1 & 0 \\
\hline Kualitas Informasi ->Manfaat & 0,3 & 0,1 & 0,3 & 0,9 & 0 \\
\hline Kualitas Layanan->Intensitas Pemakai & 0,2 & 0,4 & 0,2 & 1,4 & 0,1 \\
\hline Kualitas Layanan->Kepuasan Pemakai & 0,6 & 0,5 & 0,2 & 3,6 & 0 \\
\hline Kualitas Layanan ->Manfaat & $-0,2$ & $-0,1$ & 0,2 & 0,9 & 0 \\
\hline Kepuasan Pemakai ->Manfaat & 0,4 & 0,4 & 0,1 & 3,4 & 0 \\
\hline Kualitas Sistem ->Intensitas Pemakai & $-0,2$ & $-0,1$ & 0,2 & 0,9 & 0 \\
\hline Kualitas Sistem ->Kepuasan Pemakai & 0,3 & 0,1 & 0,3 & 1,1 & 0 \\
\hline Kualitas Sistem ->Manfaat & 0,7 & 0,7 & 0,1 & 13,1 & 0 \\
\hline
\end{tabular}

Tabel 6. Hasil Hopotesis

Berdasarkan Hasil dari tabel 6 dapat disimpulkan bebrapa hasil analisa berdasarkan hipotesis yang sudah dirancang dari awala penelitian yaitu sebagai berikut:

1. Kualitas sistem terhadap Intensitas Penguna

a) $\quad \operatorname{Ho}(1)$ : Tidak terdapat hubungan positif dan siginifikan antara variable Kualitas sistem (system quality) dengan Intensitas Pemakai (use) pendapat ini diterima

b) $\mathrm{Ha}(1):$ Terdapat hubungan positif dan siginifikan antara variable Kualitas sistem (system quality) dengan Intensitas Pemakai (use) pendapat ini ditolak

2. Kualitas sistem terhadap Tingkat kepuasan pengguna

a) $\operatorname{Ho}(2)$ : Tidak terdapat hubungan positif dan siginifikan antara variable Kualitas sistem (sistem quality) dengan kepuasan pengguna(user satisfaction) pendapat diterima

b) $\mathrm{Ha}(2)$ : Terdapat hubungan positif dan siginifikan antara variable Kualitas sistem (sistem quality) dengan kepuasan pengguna(user satisfaction) pendapat ditolak

3. Kualitas informasi terhadap Intensitas Pemakai

a) $\mathrm{Ho}(3)$ : Tidak terdapat hubungan positif dan siginifikan antara variable kualitas informasi (information quality) dengan intensitas Pemakai (use). Pendapat Diterima

b) $\mathrm{Ha}(3)$ : Terdapat hubungan positif siginifikan antara variable kualitas informasi (information quality) dengan Intensitas Pemakai (use).Pendapat DiTolak

4. Kualitas informasi terhadap Tingkat kepuasan Pengguna :

a) $\mathrm{Ho}(4)$ : Tidak terdapat hubungan positif dan siginifikan antara variable kualitas informasi (information quality) dengan kepuasan Pengguna . pendapat diTolak

b) $\mathrm{Ha}(4)$ : Terdapat hubungan positif dan siginifikan antara variable kualitas informasi (information quality) dengan kepuasan pengguna. Pendapat Diterima

5. Kualitas layanan terhadap Intensitas Penguna

a) $\quad \operatorname{Ho}(5)$ : Tidak terdapat hubungan positif dan siginifikan antara variable kualitas layanan (service quality) dengan Intensitas penggunaan (use). Diterima

b) Terdapat hubungan positif dan siginifikan antara variable kualitas layanan (servicequality) dengan penggunaan (use). ditolak

6. Kualitas layanan terhadap Tingkat kepuasan penguna 
a) $\quad \operatorname{Ho}(6)$ : Tidak terdapat hubungan positif dan siginifikan antara variable kualitas layanan (service quality) dengan kepuasan pengguna (user satisfaction). ditolak

b) $\mathrm{Ha}(6)$ : Terdapat hubungan positif dan siginifikan antara variable kualitas layanan (service quality) dengan kepuasan pengguna (user satisfaction). diterima

7. Intensitas Penggunaan terhadap kepuasan pengguna.

a) $\operatorname{Ho}(7)$ : Tidak terdapat hubungan positif dan siginifikan antara variable penggunaan (use) dengan kepuasan pengguna (user satisfaction). Ditolak

b) $\mathrm{Ha}(7)$ : Terdapat hubungan positif dan siginifikan antara variable penggunaan (use) dengan kepuasan pengguna (user satisfaction). diterima

8. Intensitas Penguna terhadap manfaat-manfaat bersih.

a) $\operatorname{Ho}(8)$ : Tidak terdapat hubungan positif dan siginifikan antara variable penggunaan (use) dengan manfaat-manfaat bersih (net benefit). Ditolak

b) $\mathrm{Ha}(8):$ Terdapat hubungan positif dan siginifikan antara variable penggunaan (use) dengan manfaat-manfaat bersih (net benefit).diterima

9. Kepuasan pengguna terhadap manfaat-manfaat bersih.

a) $\quad \operatorname{Ho}(9)$ : Tidak terdapat hubungan positif dan siginifikan antara variable kepuasan pengguna (user satisfaction) dengan manfaat-manfaat bersih (net benefit).ditolak

b) $\mathrm{Ha}(9)$ : Terdapat hubungan positif dan siginifikan antara variable kepuasan pengguna (user satisfaction) dengan manfaat-manfaat bersih (net benefit). diterima

\section{KESIMPULAN DAN SARAN}

Penelitian ini mengadopsi penelitian DeLone and Mc Lean dalam mengukur Intensitas Kepuasan dan Pemanfaatan Informasi Website Kecamatan Jonggol Dari 9 hipotesis yang diuji didapatkan 5 yang signifikan. Adapun 5 hipotesis yang signifikan adalah pengaruh positif kualitas Layanan terhadap kepuasan penguna, Pengaruh positif intensitas pengguna terhadap Kulaitas layanan , Pengaruh Positif Kepuasan Penguna dengan manfaat dan pengaruh positif Intentistas Penguna dengan Manfaat . Dari hasil hipotesis beberapa peryanyaan dari hipotesis terjawab yaitu

1. Apakah kualitas informasi berpengaruh positif terhadap kepuasan pengguna Website Kecamatan Jonggol ? diterima .

2. Apakah kualitas sistem berpengaruh positif terhadap kepuasan pengguna Website? Ditolak

3. Apakah kualitas layanan berpengaruh positif terhadap kepuasan pengguna Website ? diterima

4. Apakah kualitas informasi berpengaruh positif terhadap intensitas penggunaan Website ? ditolak

5. Apakah kualitas sistem berpengaruh positif terhadap intensitas penggunaan Website ? ditolak

6. Apakah kualitas layanan berpengaruh positif terhadap intensitas penggunaan Website ?diterima

7. Apakah intensitas penggunaan sistem dan kepuasan pengguna sistem berpengaruh positif terhadap net benefit ? Diterima

Saran-saran yang diajukan penulis sesuai dengan penelitian yang telah dilakukan adalah:

1. Peningkatan kualitas layanan Web Kecamatan Jonggol Kabupaten bogor harus lebih diperhatikan karena selain sebagai sarana Penyebaran Informasi juga sebagai sarana Pemersatu

2. Masih Kurangnya Minat Penduduk dalam Mengetahui Informasi Kergiatan daerahnya

3. Masih kurangnya Akses Internet karena penyebaran penduduk dan Topologi daerah yang berbukit bukit.

4. Tantangan bagi pemerintah dalam penyebaran akses internet yang merata .

\section{DAFTAR PUSTAKA}

Ghozali, I. 2011. Structural Equation Modeling Metode Alternatif dengan Partial Least SquarePLS, Edisi 3. Semarang: Badan Penerbit Universitas Dipenogoro.

Jogiyanto, H.M. 2007. Model Kesuksesan Teknologi Informasi. Yogyakarta: C.V Andi Offset. Nanang Asnadi, 2012 "Analisis Faktor Kesuksesan Aplikasi Ticares Sales untuk Bisnis Jasa Suliyanto. 2011. Ekonometrika Terapan, Teori dan Aplikasi dengan SPSS : C.V Andi Offset. Sumarni, M.; \& Wahyuni, S. 2006. Metodologi Penelitian Bisinis. Yogyakarta: C.V Andi Offset. Sutan, Indra Mangara. 2009 "Model Kesuksesan Delone Dan Mclean Pada Penggunaan Ecommerce di Perusahaan Ritel" Tesis, Universitas Gadjah Mada. 